\title{
Transient receptor potential melastatin 4 and cell death
}

\author{
J. Marc Simard • S. Kyoon Woo • Volodymyr Gerzanich
}

Received: 24 September 2012 /Revised: 25 September 2012 / Accepted: 25 September 2012 /Published online: 13 October 2012

(C) The Author(s) 2012. This article is published with open access at Springerlink.com

\begin{abstract}
Cell death proceeds by way of a variety of "cell death subroutines," including several types of "apoptosis," "regulated necrosis," and others. "Accidental necrosis" due to profound adenosine triphosphate (ATP) depletion or oxidative stress is distinguished from regulated necrosis by the absence of death receptor signaling. However, both accidental and regulated necrosis have in common the process of "oncosis," a physiological process characterized by $\mathrm{Na}^{+}$ influx and cell volume increase that, in necrotic cell death, is required to produce the characteristic features of membrane blebbing and membrane rupture. Here, we review emerging evidence that the monovalent cation channel, transient receptor potential melastatin 4 (TRPM4), is involved in the cell death process of oncosis. Potential involvement of TRPM4 in oncosis is suggested by the fact that the two principal regulators of TRPM4, intracellular ATP and $\mathrm{Ca}^{2+}$, are both altered during necrosis in the direction that causes TRPM4 channel opening. Under physiological conditions, activation of TRPM4 promotes $\mathrm{Na}^{+}$influx and cell depolarization. Under pathological conditions, unchecked activation of TRPM4 leads to $\mathrm{Na}^{+}$overload, cell volume increase, blebbing and cell membrane rupture, the latter constituting the irreversible end stage of necrosis.
\end{abstract}

\author{
J. M. Simard $(\bowtie) \cdot$ S. K. Woo $\cdot$ V. Gerzanich \\ Department of Neurosurgery, \\ University of Maryland School of Medicine, \\ 22 S. Greene Street, Suite S12D, \\ Baltimore, MD 21201-1595, USA \\ e-mail: msimard@smail.umaryland.edu \\ J. M. Simard \\ Department of Pathology, \\ University of Maryland School of Medicine, \\ Baltimore, MD, USA \\ J. M. Simard \\ Department of Physiology, \\ University of Maryland School of Medicine, \\ Baltimore, MD, USA
}

Emerging data indicate that TRPM4 plays a crucial role as end executioner in the accidental necrotic death of ATPdepleted or redox-challenged endothelial and epithelial cells, both in vitro and in vivo. Future studies will be needed to determine whether TRPM4 also plays a role in regulated necrosis and apoptosis.

Keywords TRPM4 $\cdot$ Necrosis $\cdot$ Apoptosis $\cdot$ Oncosis Sodium $\cdot$ Depolarization $\cdot$ Review

\section{Introduction}

Transient receptor potential (TRP) melastatin 4 (TRPM4) is a member of a large superfamily consisting of 28 mammalian cation channels. All but two TRP channels are permeable to divalent cations. The exceptions, TRPM4 and TRPM5, are non-selective, $\mathrm{Ca}^{2+}$-impermeable channels that transport monovalent cations exclusively [76]. TRPM4 and TRPM5 are both activated by increasing intracellular $\mathrm{Ca}^{2+}$. With TRPM4, ATP plays a crucial role in maintaining $\mathrm{Ca}^{2+}$ sensitivity through direct binding to the channel protein [77]. TRPM4, but not TRPM5, is blocked by intracellular ATP, i.e., is activated by decreasing intracellular ATP. Excellent reviews on the biophysical properties and physiological regulation of these channels have been published $[40,56,59,108,110]$.

The best known function of TRPM4, the regulation of $\mathrm{Ca}^{2+}$ influx, is linked to one of the principal factors that regulates channel opening - the intracellular $\mathrm{Ca}^{2+}$ concentration $[55,56,72,77]$. TRPM4 is activated following receptor-mediated $\mathrm{Ca}^{2+}$ mobilization, with activation causing depolarization of the cell membrane. Because the electrochemical driving force for $\mathrm{Ca}^{2+}$ is determined by the cell membrane potential, the reduction in membrane potential induced by activation of TRPM4 reduces the driving force for $\mathrm{Ca}^{2+}$ entry through $\mathrm{Ca}^{2+}$-permeable pathways. However, this mechanism for regulating $\mathrm{Ca}^{2+}$ entry may be dangerous, 
as it risks $\mathrm{Na}^{+}$overload. As discussed below, $\mathrm{Na}^{+}$overload plays a crucial role in cell death processes.

Surprisingly, the second major factor that regulates channel opening, the intracellular concentration of ATP, has a more obscure functional role. As noted above, ATP binding to the channel helps to maintaining $\mathrm{Ca}^{2+}$ sensitivity [77]. However, the functional role of channel block by intracellular ATP is uncertain. It has been speculated that this property confers sensitivity to the metabolic state of the cell [78], but whether this occurs under physiological conditions, and what its implications might be are unclear. The concentration of ATP that yields half-maximum open channel probability is $<5 \mu \mathrm{M}$, far below the normal operating levels of 1-6 mM cytoplasmic ATP found in mammalian cells [10]. The only metabolic state associated with such levels of ATP is one of severe metabolic depletion bordering on cell death. This property of TRPM4 also may be dangerous, as it risks persistent channel opening if metabolic conditions are not rapidly improved and cellular levels of ATP are not adequately restored. Again, unchecked channel opening can lead to $\mathrm{Na}^{+}$overload and its deleterious consequences, including cell death.

Despite its relatively recent discovery, much has been written about this unique ion channel. Excellent reviews of a general nature as well as specialized reviews focused on organ systems have been published $[3,17,29,32,38,42,79,91$, 107]. There is growing recognition that TRPM4 plays a crucial role in a variety of diseases [74, 80]. Recent work has shown that mutations in the TRPM4 gene are responsible for certain cardiac conduction diseases [51, 60, 68, 93, 102]. In addition, TRPM4 plays a central role in cardiac hypertrophy $[37,39,81]$, certain forms of hypertension [65], cutaneous anaphylaxis [32, 111], certain types of cancer [5, 57, 89], as well as spinal cord injury $[35,98]$. However, one topic that has gained relatively little attention is the role of TRPM4 in cell death. Other transient receptor potential channels have been implicated in cell death, typically linked to $\mathrm{Ca}^{2+}$ influx $[1,2$, $66,67,97]$. Here, we review emerging data in which specific involvement of TRPM4 in accidental necrotic cell death has been shown, and we speculate on potential involvement in regulated necrosis and in apoptosis, which is theoretically possible but has yet to be demonstrated.

\section{Necrotic cell death}

First, because of the variable usage in the nomenclature of cell death, it is appropriate to begin with a clarification of our usage of terms. Traditionally, different types of cell death were classified based on morphological features and included "apoptosis," "necrosis" and "mitotic catastrophe" [50]. Currently, a functional classification of "cell death subroutines" is favored that is defined by a series of precise, measurable biochemical features, and includes "extrinsic apoptosis," "caspase-dependent or - independent intrinsic apoptosis," "regulated necrosis," "autophagic cell death" and "mitotic catastrophe," with these classifications applying both in vitro and in vivo [33, 34].

The current functional classification of cell death [34] is ambiguous as to whether necrosis in the context of severe ATP depletion or oxidative stress (absent death receptor signaling) should be termed "accidental necrosis" or "regulated necrosis." Here, in keeping with tradition, we refer to it as accidental necrosis. The current classification does not include the term "oncosis" [34], which has been used by some authors to denote a form of necrotic cell death, i.e., necrotic death resulting from oncosis. Here, we use the term oncosis exclusively to refer to the physiological process of cell volume increase, in accord with the usage proffered by the Nomenclature Committee on Cell Death [50]. In this sense, oncosis is a process that is shared by both accidental and regulated necrosis. Thus, accidental necrosis can result either from oncosis (e.g., ATP depletion or oxidative stress) or from extremely harsh physical conditions (e.g., freezethaw cycles) [34].

Necrotic cells share specific morphological traits, including an increasingly translucent cytoplasm, the osmotic swelling of organelles, minor ultrastructural modifications of the nucleus (the dilatation of the nuclear membrane and the condensation of chromatin into small patches) and an increase in cell volume (oncosis), which culminates in the breakdown of the plasma membrane and loss of intracellular contents [33, 47, 50]. Necrotic cells do not fragment into discrete bodies, as their apoptotic counterparts do, nor do their nuclei, which may accumulate in necrotic tissues.

In necrosis, opening of the mitochondrial inner membrane permeability transition pore can cause irreversible mitochondrial inner membrane depolarization and osmotic mitochondrial lysis, impairing ATP formation and leading to massive energy depletion [49, 88, 90]. Mitochondrial swelling eventually ruptures the outer mitochondrial membrane, releasing intermembrane proteins. Other prominent features include formation of reactive oxygen species, activation of non-apoptotic proteases, and a large increase of intracellular $\mathrm{Ca}^{2+}$. Elevated $\mathrm{Ca}^{2+}$ activates $\mathrm{Ca}^{2+}$-dependent proteases, such as calpains $[61,62]$, and triggers mitochondrial $\mathrm{Ca}^{2+}$ overload, leading to further depolarization of the inner mitochondrial membrane and inhibition of ATP production.

Absent direct physical destruction, accidental necrotic cell death, for example death due to severe ATP depletion or oxidative stress, requires that two events transpire: (1) the cytoskeleton first must become disrupted; (2) intracellular pressure must act to expand the cell volume (oncosis), resulting initially in blebbing and culminating in cell membrane rupture. Blebbing occurs when the cell membrane detaches from the cytoskeleton and is forced outward by intracellular pressure [106] (Fig. 1). 

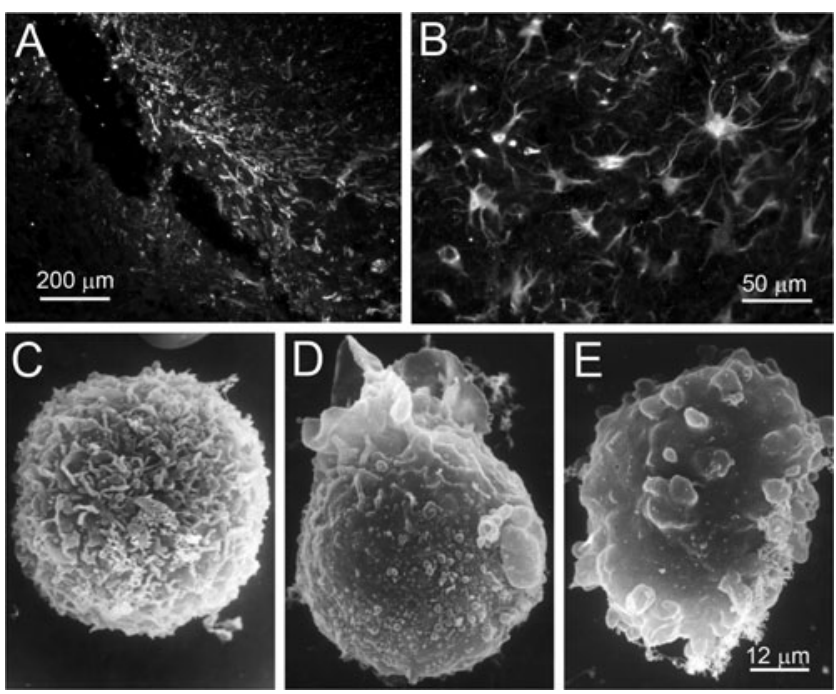

Fig. 1 Cells expressing TRPM4 are highly susceptible to ATPdepletion-induced cell blebbing. a, b Immunolabeling for TRPM4 shows that native reactive astrocytes in situ that form a gliotic capsule surrounding a foreign body exhibit abundant expression of TRPM4 (Simard and colleagues, unpublished). $\mathbf{c}-\mathbf{e}$ Scanning electron micrographs of freshly isolated native reactive astrocytes from a gliotic capsule showing that ATP depletion $(1 \mathrm{mM}$ sodium azide) induces oncotic blebbing; formaldehyde-glutaraldehyde fixed cells were imaged under control conditions (c), 5 min after exposure to sodium azide (d), and $25 \mathrm{~min}$ after exposure to sodium azide (e); bar, $12 \mu \mathrm{m}$; from Chen and Simard [24]

\section{ATP depletion}

ATP depletion is a typical feature of necrosis. Initiation of necrosis generally requires that ATP levels be depleted by 80 $85 \%$ or more $[50,63]$. ATP depletion due to factors external to the cell, e.g., following a traumatic insult or an ischemic event without reperfusion, results in accidental necrosis. The situation is more complex in the case of regulated necrosis. It is generally acknowledged that maintenance of ATP stores is required, at least initially, to pursue any form of programmed cell death, including regulated necrosis. Some evidence suggests that ATP-depletion may not be an absolute requirement for regulated necrosis [82]. However, in the type of regulated necrosis induced by tumor necrosis factor (TNF), which is called necroptosis, ATP-consuming processes including poly (ADP-ribose) polymerase-1 (PARP1) activity, translation and proteasome-mediated degradation persist and hence may contribute to the lethal decline in intracellular ATP $[58,109]$. In addition, TNF induces receptor-interacting protein (RIP)-dependent inhibition of adenine nucleotide translocase (ANT)mediated transport of ADP into mitochondria, which reduces ATP production and contributes further to the lethal decline in intracellular ATP [105]. In necroptosis induced by TNFrelated apoptosis inducing ligand (TRAIL) at acidic extracellular $\mathrm{pH}$, TRAIL gives rise to an early, $90 \%$ depletion of intracellular ATP that is PARP-1-dependent [45]. Thus, in general, ATP depletion can be considered a characteristic feature of both accidental and regulated necrosis.

ATP depletion has striking effects on cytoskeletal structure and function. Disruption of actin filaments (F-actin) during ATP-depletion reflects predominantly the severing or fragmentation of F-actin [115], with depolymerization playing a contributory role [96]. Actin sequestration progresses in a duration-dependent manner, occurring as early as $15 \mathrm{~min}$ after onset of anoxia, when cellular ATP drops to $<5 \%$ of control levels [114]. Alterations in membrane-cytoskeleton linker proteins (spectrin, ankyrin, ezrin, myosin- $1 \beta$ and others) $[73,95,113]$ induced by ATP depletion weaken membranecytoskeleton interactions, setting the stage for the later formation of blebs $[22,23,70]$. After 30 min of ATP depletion, the force required to pull the membrane away from the underlying cellular matrix diminishes by $>95 \%$, which coincides with the time of bleb formation [27]. During ATP depletion, the strength of "membrane retention" forces diminishes until intracellular pressures become capable of initiating and driving membrane bleb formation.

Initially, as ATP-depleted cells swell and bleb, their plasma membranes remain "intact," appearing to be under tension, yet becoming increasingly permeable to macromolecules [28]. As energy depletion proceeds, the plasma membrane becomes permeable to larger and larger molecules, a phenomenon that has been divided into three phases [22, 23]. In phases 1, 2, and 3 , respectively, plasma membranes become permeable first to propidium iodide (PI; $668 \mathrm{Da}$ ), then to $3-\mathrm{kDa}$ dextrans, and finally to $70-\mathrm{kDa}$ dextrans or lactate dehydrogenase $(140 \mathrm{kDa})$. Phase 1 , which is marked by an increase in permeability to PI, is said to be reversible by reoxygenation $[22,106]$, an observation that would seem to conflict with the notion that PI uptake is a hallmark of necrotic cell death [50]. In any case, these observations on increasing permeability indicate that blebs do not actually have to rupture in order to begin the pre-morbid exchange of vital substances between the intracellular and extracellular compartments.

\section{Oncosis}

Regulated and accidental forms of necrosis share several characteristic features. Not only is ATP depleted in both forms, but both also are characterized by cytoplasmic swelling (oncosis) and rupture of the plasma membrane [50]. Initially, cellular injury causes the formation of membrane blebs. Later, if the injurious stimulus persists, membrane blebs rupture and cell lysis occurs. Blebbing and membrane rupture are two essential features that characterize necrotic cell death [7, 47].

The loss of cytoskeletal support alone is not sufficient for anoxic plasma membrane disruption [21, 94]. In addition, an outward force is necessary to cause the cell to expand and for blebs to form. This outward force is provided by osmotic 
pressure, and it results in the process termed oncosis $[26,106]$. The greater the osmotic pressure, the more rapidly blebs expand and rupture, resulting in frank irreversible disruption of the cell membrane.

One certain way to increase cellular osmotic pressure is to increase the influx of $\mathrm{Na}^{+}$[20]. Indeed, necrosis has been said to require a combination of low ATP and high $\mathrm{Na}^{+}$ intracellularly [7]. Because $\mathrm{Na}^{+}$is naturally excluded from the intracellular compartment, there normally exists a large electrochemical driving force for its passive inward transport. Increasing the influx of $\mathrm{Na}^{+}$inevitably increases the inward driving force for $\mathrm{Cl}^{-}$, which helps to maintain intracellular electrical neutrality. The resulting increase in osmotically active $\mathrm{Na}^{+}$and $\mathrm{Cl}^{-}$ions intracellularly drives the influx of $\mathrm{H}_{2} \mathrm{O}$, initiating cell swelling and culminating in membrane bleb formation.

One of several mechanisms involving altered function of active or passive ion transporters may give rise to the increase in intracellular $\mathrm{Na}^{+}$that drives necrosis. Historically, it was thought that a key deleterious effect of ATP depletion was the loss in function of the active ion transporter, $\mathrm{Na}^{+}-$ $\mathrm{K}^{+}$ATPase, which normally extrudes $\mathrm{Na}^{+}$from the cell. Loss of function of $\mathrm{Na}^{+}-\mathrm{K}^{+}$ATPase results in a slow accumulation of $\mathrm{Na}^{+}$intracellularly that is associated with slow depolarization. However, accumulating intracellular $\mathrm{Na}^{+}$in this manner is not inevitably associated with an increase in intracellular pressure sufficient to produce necrosis. In energized cells, osmotic swelling induced by $\mathrm{Na}^{+}-\mathrm{K}^{+}$ATPase inhibition with ouabain that is sufficient to cause a doubling of the cell volume does not produce blebbing or cell death [46]. Moreover, the effect of ouabain on cell death may be cell-specific. In some cells, the death signal is mediated by an interaction between ouabain and the $\mathrm{Na}^{+}-\mathrm{K}^{+}$ATPase $\alpha$ subunit but is independent of the inhibition of $\mathrm{Na}^{+}-\mathrm{K}^{+}$ pump-mediated ion fluxes and elevation of the $\left[\mathrm{Na}^{+}\right]_{i}\left[\mathrm{~K}^{+}\right]_{\mathrm{i}}$ ratio $[83,84]$. Overall, $\mathrm{Na}^{+}-\mathrm{K}^{+}$ATPase inhibition may produce no death [85], only necrotic death [86], or a "mixed" form of death, with features of both necrosis and apoptosis in various cell types [83, 84, 87, 116, 118]. It is clear that, by itself, $\mathrm{Na}^{+}-\mathrm{K}^{+}$ATPase inhibition is inadequate to account broadly for necrosis.

Alternatively, sodium influx may be augmented by opening a non-selective cation channel such as TRPM4. Pharmacological inhibition of non-selective cation channels using flufenamic acid abolishes cytosolic $\mathrm{Ca}^{2+}$ overload, cell swelling and necrosis of liver cells exposed to freeradical donors [8]. Implicating TRPM4 specifically in necrotic death makes theoretical sense, since the two principal regulators of TRPM4, intracellular ATP and $\mathrm{Ca}^{2+}[40,59$, 110], are both characteristically altered during necrosis and, moreover, are altered in the direction that causes TRPM4 channels to open: a decrease in intracellular ATP (see above) and an increase in intracellular $\mathrm{Ca}^{2+}[61,62]$.
Involvement of TRPM4 in cell blebbing and necrotic cell death was shown first by Gerzanich et al. [35]. That this study involved accidental and not regulated necrosis was assured by the experimental design: COS-7 cells expressing TRPM4 were depleted rapidly of ATP, down to $<2 \%$ of control levels within $15 \mathrm{~min}$, in the absence of TNF $\alpha$ or any other inducer of death receptor signaling. ATP depletion activated a $25-\mathrm{pS} \mathrm{Cs}^{+}$-permeable non-selective cation channel that was blocked by $N$-methyl-D-glucamine, characteristic of TRPM4. In COS-7 cells expressing TRPM4, ATP depletion caused marked cell blebbing, oncotic swelling and membrane leakage, and resulted in nuclear labeling by PI, consistent with necrotic cell death (Fig. 2).

Notably, in the study by Gerzanich et al. [35], ATP depletion did not induce necrotic death in COS-7 cells that did not express TRPM4. This finding is consistent with the observations above that the loss of cytoskeletal support or of $\mathrm{Na}^{+}-\mathrm{K}^{+}$ ATPase activity induced by ATP depletion is not sufficient to obtain plasma membrane disruption. Moreover, this finding indicates that in some cells, TRPM4 plays an obligate role as end executioner in necrotic cell death.

A distinct feature of heterologously expressed TRPM4 channels is that, upon activation by intracellular $\mathrm{Ca}^{2+}$, currents exhibit a fast decay due to a decrease in apparent sensitivity to $\mathrm{Ca}^{2+}[56,75,78]$. This phenomenon could, in principal, act to protect cells from necrotic death by limiting $\mathrm{Na}^{+}$influx.

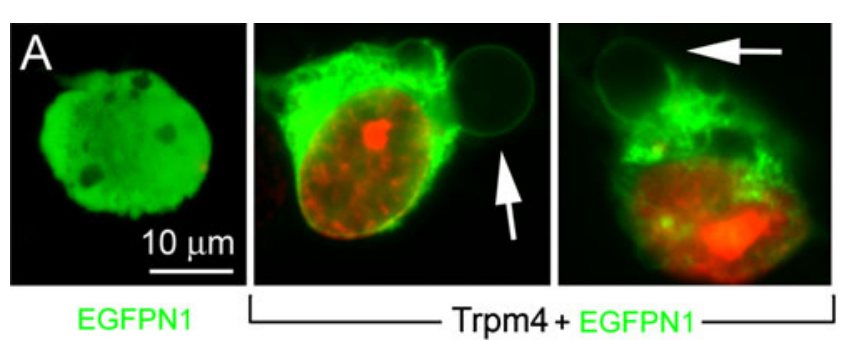

B

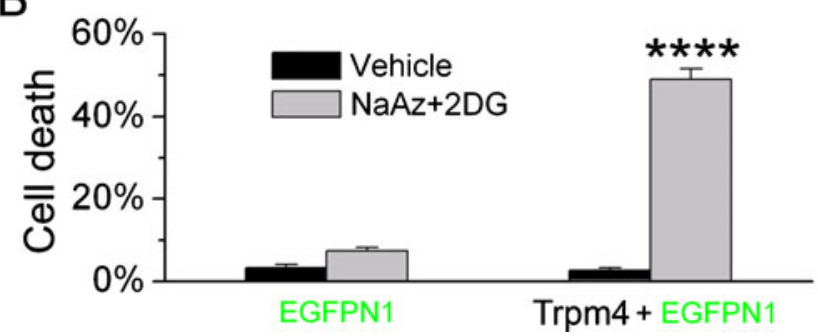

Fig. 2 TRPM4 plays an obligate role in necrotic cell death in vitro. a Oncotic blebbing and nuclear labeling with propidium iodide (PI; red) induced by ATP depletion ( $1 \mathrm{mM}$ sodium azide plus $10 \mathrm{mM} \mathrm{2-}$ deoxyglucose $[\mathrm{NaAz}+2 \mathrm{DG}])$ in COS-7 cells transfected with EGFPN1 + TRPM4 plasmid, but not in cells transfected with EGFPN1 plasmid alone. b Quantification of PI-positive necrotic cell death induced 10 min after ATP depletion in COS-7 cells transfected with EGFPN1 + TRPM4 plasmid or with EGFPN1 plasmid alone; values represent the percentage of the transfected cells (green cytoplasm) with nuclear PI labeling; experiments were performed in triplicate, with data from $>100$ cells per experiment; $* * * * P<0.0001$; from Gerzanich et al. [35] 
However, in HEK 293 cells expressing TRPM4, $\mathrm{H}_{2} \mathrm{O}_{2}$ was found to eliminate TRPM4 desensitization in a dosedependent manner [99]. Site-directed mutagenesis revealed that the Cys ${ }^{1093}$ residue of TRPM4 is crucial for the $\mathrm{H}_{2} \mathrm{O}_{2}$-mediated reversal of desensitization. In the same study, it was shown that in HeLa cells, which endogenously express TRPM4, $\mathrm{H}_{2} \mathrm{O}_{2}$ (without ATP depletion) elicited necrosis as well as apoptosis, and that $\mathrm{H}_{2} \mathrm{O}_{2}$-mediated necrosis, but not apoptosis, was abolished by replacing external $\mathrm{Na}^{+}$with $N$-methyl-D-glucamine or by knocking down TRPM4 with shRNA. Thus, removing TRPM4 desensitization by oxidative stress assures that TRPM4 will participate fully, without the impediment of desensitization, in the process of necrotic death.

TRPM4 recently was shown to be involved in the necrotic death of endothelial cells following exposure to lipopolysaccharide (LPS) [9]. Exposing human umbilical vein endothelial cells to LPS caused upregulation of TRPM4-like currents and caused $\mathrm{Na}^{+}$overload, cell depolarization, cell volume increase and $\mathrm{Na}^{+}$-dependent necrotic cell death, as measured by release of lactate dehydrogenase. The cells were protected against LPS-induced necrotic death by 9-phenanthrol, a relatively selective inhibitor of TRPM4, by siRNA directed against TRPM4, as well as by suppression of TRPM4 using a dominant negative mutant.

TRPM4 is involved in necrotic death in vivo as well, as shown first by Gerzanich et al. [35]. In this study, traumatic injury to the spinal cord was accompanied by delayed capillary fragmentation, resulting in the autodestructive process termed "progressive hemorrhagic necrosis." Microvessels in the penumbra of injury showed prominent upregulation of TRPM4 mRNA and protein, which was not present in tissues remote from the injury. Capillary fragmentation was attributed to necrotic death of microvascular endothelial cells (Fig. 3). TRPM4-/- mice were completely spared from capillary fragmentation and progressive hemorrhagic necrosis. Moreover, rats that were subjected to a similar traumatic insult and that were administered antisense oligodeoxynucleotide directed against TRPM4 also were spared from capillary fragmentation and progressive hemorrhagic necrosis. The latter series of experiments also showed that antisense entered microvascular endothelial cells in the penumbra almost exclusively, and thereby prevented the destruction (fragmentation) of microvessels (Fig. 3). Together, these findings are consistent with TRPM4 playing an obligate role as end executioner in necrotic cell death in vivo.

TRPM4 is not the only ion channel that can transport $\mathrm{Na}^{+}$ in a manner sufficient to cause oncosis in the context of ATP depletion. Many other ion channels passively transport $\mathrm{Na}^{+}$ down its electrochemical gradient, either selectively, e.g., voltage dependent $\mathrm{Na}^{+}$channels, or non-selectively, e.g., non-selective cation channels such as $N$-methyl-D-aspartate (NMDA) receptor channels and some TRP channels, some of which transport both monovalent and divalent cations.
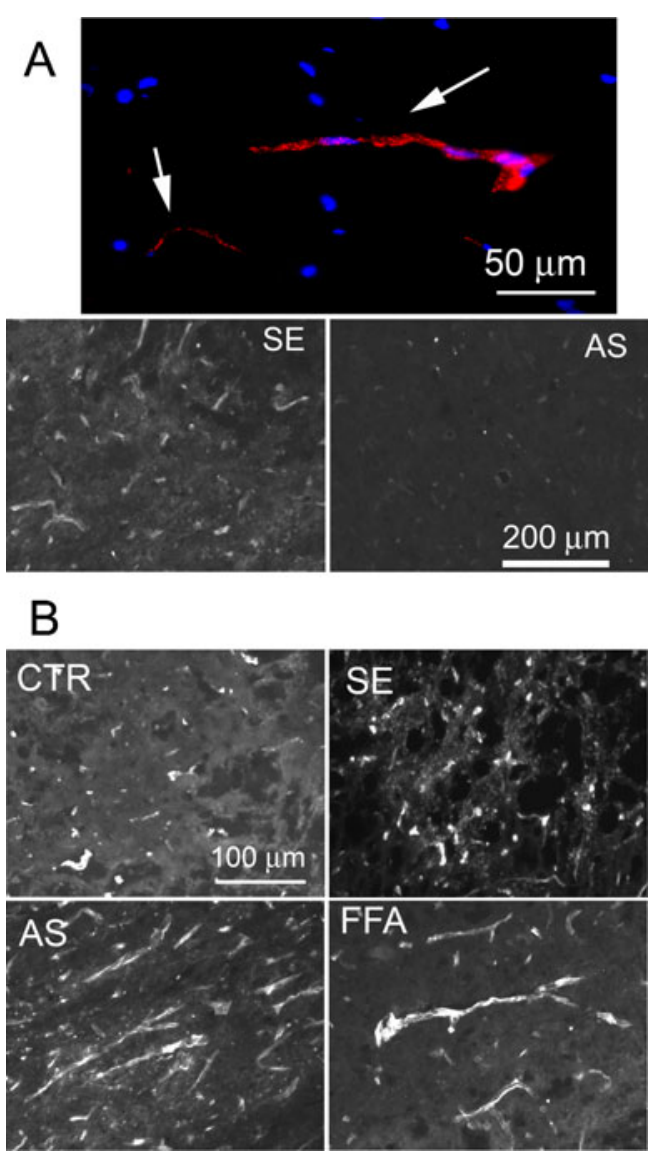

Fig. 3 TRPM4 plays an obligate role in necrotic cell death in vivo. a Upper panel: fluorescence image of the penumbra $24 \mathrm{~h}$ after spinal cord injury $(S C I)$ in a rat administered CY3-conjugated TRPM4 antisense $(A S)$ oligodeoxynucleotide (red) by constant infusion post-SCI, showing that AS preferentially targets microvessels after SCI; rat perfused to remove intravascular contents; nuclei labeled with 4 ',6diamidino-2-phenylindole (DAPI; blue); arrows point to capillaries; lower panel: immunohistochemistry for TRPM4 in tissues obtained $24 \mathrm{~h}$ post-SCI from rats administered TRPM4-sense (SE) or TRPM4AS, showing reduced TRPM4 expression with AS. b Spinal cord sections from an untreated control rat $(C T R)$ and rats administered TRPM4-SE, TRPM4-AS or flufenamic acid (FFA), showing necrosisinduced capillary fragmentation in the controls (CTR and SE) and preservation of intact capillaries with gene suppression or pharmacological block of TRPM4; from Gerzanich et al. [35]

However, with many non-selective cation channels including NMDA and many TRP, distinguishing between effects due to $\mathrm{Na}^{+}$transport versus $\mathrm{Ca}^{2+}$ overload is difficult, and indeed, pronecrotic effects of these channels are typically attributed to $\mathrm{Ca}^{2+}$ influx. Other examples abound wherein $\mathrm{Na}^{+}$influx is induced and is associated with oncosis and necrotic cell death, including such activators as venom from the wasp, Nasonia vitripennis [92] and a cytotoxic antibody that kills undifferentiated human embryonic stem cells [104]. However, none of these channels exhibits the unique combination of properties seen with TRPM4 of being activated by a decrease in ATP and an increase in $\mathrm{Ca}^{2+}$. Additional work will be required to determine the role of many of 
these channels specifically in passive $\mathrm{Na}^{+}$transport that is requisite for necrotic cell death.

\section{Apoptotic cell death}

Unlike accidental necrosis, apoptosis is a metabolically active, energy demanding process that maintains cellular ATP levels and plasma membrane integrity until late in the cell death process. Comprehensive reviews on the molecular machinery involved in apoptosis have been published. Here, we focus on the role of $\mathrm{Na}^{+}$influx and the potential involvement of TRPM4

Like necrosis, apoptotic cell death has features of $\mathrm{Na}^{+}$ dependence and cell membrane depolarization [12-15, 31, 87]. A variety of apoptotic stimuli result in an early transient increase in intracellular $\mathrm{Na}^{+}$that is associated with marked plasma membrane depolarization that occurs prior to and after cell shrinkage [15]. In thymocytes, $\mathrm{Na}^{+}$influx plays a major role in the rapid phosphatidylserine exposure induced by P2X7 receptor activation [25]. In Jurkat cells, inhibition of $\mathrm{Na}^{+}$influx by ion substitution reduces Fas-induced apoptosis [13]. An initial $\mathrm{Na}^{+}$influx is necessary for cell shrinkage, but not for the activation of the cell death effectors, whereas $\mathrm{K}^{+}$ efflux is critical for cell shrinkage and death by apoptosis. Downstream mechanisms activated by the rise in $\mathrm{Na}^{+}$are not completely elucidated, but may include activation of a $\mathrm{Na}^{+}$ $\mathrm{Ca}^{2+}$ exchanger, resulting in $\mathrm{Ca}^{+}$overload $[11,54,69]$. In addition, $\mathrm{Na}^{+}$overload may be involved in opening of the mitochondrial inner membrane permeability transition pore and mitochondrial swelling, resulting in cytochrome $c$ release and activation of the caspase-3-dependent apoptosis [30].

Several mechanisms have been postulated to account for the early rise of intracellular $\mathrm{Na}^{+}$in apoptosis, including diminished function of $\mathrm{Na}^{+}-\mathrm{K}^{+}$ATPase, augmented function of voltage-dependent $\mathrm{Na}^{+}$channels, and augmented function of non-selective cation channels (see review by Franco et al. [31]). In general, changes in $\mathrm{Na}^{+}$and $\mathrm{K}^{+}$fluxes typical of apoptosis are likely to be caused by a complex interplay of several mechanisms, including a decrease in $\mathrm{Na}^{+}-\mathrm{K}^{+}$ATPase activity, $\mathrm{Na}^{+}-\mathrm{Cl}^{-}$co-transport and an increase in $\mathrm{Na}^{+}$channel permeability [112].

Reflecting on the potential involvement of voltagedependent $\mathrm{Na}^{+}$channels is instructive. Unlike $\mathrm{Na}^{+}-\mathrm{K}^{+}$ATPase and non-selective cation channels, voltage-dependent $\mathrm{Na}^{+}$ channels are highly selective passive transporters of $\mathrm{Na}^{+}$, leaving little doubt about the event that triggers apoptosis. Activation of voltage-dependent $\mathrm{Na}^{+}$channels during oxygen deprivation leads to apoptotic neuronal death that is reduced by the highly specific $\mathrm{Na}^{+}$channel blocker, tetrodotoxin [6] Veratridine, which prevents inactivation of voltage-dependent $\mathrm{Na}^{+}$channels, increases influx of $\mathrm{Na}^{+}$, causes cell depolarization, and induces apoptosis of neuronal cells [19, 36, 44, 117]. Following global cerebral ischemia in the gerbil, administration of the $\mathrm{Na}^{+}$ionophore, monensin, or of the $\mathrm{Na}^{+}$channel blocker, tetrodotoxin, results in an increase or a decrease, respectively, in apoptotic neuronal death in the hippocampus [16]. A gain-offunction mutation [the $\mathrm{N}(1325) \mathrm{S}$ mutation] in the cardiac $\mathrm{Na}^{+}$ channel gene SCN5A results in an increase in apoptotic cell death of ventricular myoctes [119]. Such studies demonstrate the crucial role played by an early rise in $\mathrm{Na}^{+}$in the cell death subroutine of apoptosis.

In some cases, a non-selective cation channel such as TRPM4 may be responsible for the early rise in intracellular $\mathrm{Na}^{+}$involved in apoptosis. The involvement of non-selective cation channels in apoptosis has been widely reported in many cell types following exposure to various apoptotic stimuli [41, $43,48,52,53,64,71,101,103]$. However, most of the studies on non-selective cation channels attributed cell death signaling to a rise in intracellular $\mathrm{Ca}^{2+}$, with little consideration for the potential role of intracellular $\mathrm{Na}^{+}$or of cell membrane potential.

A number of cells have been found to express a channel with properties of TRPM4 that could mediate an early rise in $\mathrm{Na}^{+}$ that may trigger apoptosis. $\mathrm{H}_{2} \mathrm{O}_{2}$, an inducer of apoptosis in epithelial cells $[4,18]$, increases the activity of a $24 \mathrm{pS} \mathrm{Ca}^{2+}$. activated, non-selective cation channel in a bronchial epithelial cell line [43], and of a $19 \mathrm{pS} \mathrm{Ca}^{2+}$-activated, ATP-sensitive nonselective cation channel in a liver-derived epithelial cell line [100]. Both of these studies are reminiscent of the effect of $\mathrm{H}_{2} \mathrm{O}_{2}$ on TRPM4 in endothelial cells [99]. Conversely, $\mathrm{H}_{2} \mathrm{O}_{2}$ induced apoptosis in HeLa cells, which express TRPM4, is not blocked by inhibiting $\mathrm{Na}^{+}$influx with ion substitution [99]. Despite theoretical data pointing to a potential role of TRPM4 in triggering apoptosis, to our knowledge, there has been no molecular demonstration of this to date.

\section{Summary}

Cell death is extraordinarily complex, with new molecular insights continuing to emerge at a rapid pace. The molecular events involved in apoptosis have been extensively studied, but by comparison, the molecular basis for necrosis is less well understood. Much progress has been realized during the last decade, not the least important of which is the recognition that necrosis may proceed by accidental as well as by regulated pathways, with both requiring $\mathrm{Na}^{+}$influx to drive oncosis that is responsible for membrane blebbing and rupture. A variety of TRP channels have been implicated in apoptotic and necrotic cell death, typically related to $\mathrm{Ca}^{2+}$ influx [1, 2, 66, 67, 97]. Emerging evidence indicates that the monovalent cation channel, TRPM4, which under physiological conditions promotes $\mathrm{Na}^{+}$influx and cell depolarization, plays a crucial role as end executioner in the accidental necrotic death of ATPdepleted or redox-challenged endothelial and epithelial 
cells, both in vitro and in vivo. TRPM4 may also play a role in regulated necrosis and apoptosis, although future studies will be required to elucidate this.

Acknowledgments This work was supported by grants to JMS from the Department of Veterans Affairs (Baltimore), the National Institute of Neurological Disorders and Stroke (NINDS) (NS060801; NS061808), the National Heart, Lung and Blood Institute (HL082517), and the Department of the Army (W81XWH 1010898); to VG from NINDS (NS061934; NS072501).

Open Access This article is distributed under the terms of the Creative Commons Attribution License which permits any use, distribution, and reproduction in any medium, provided the original author(s) and the source are credited.

\section{References}

1. Aarts MM, Tymianski M (2005) TRPM7 and ischemic CNS injury. Neuroscientist 11:116-123

2. Aarts MM, Tymianski M (2005) TRPMs and neuronal cell death. Pflugers Arch 451:243-249

3. Abriel H, Syam N, Sottas V, Amarouch MY, Rougier JS (2012) TRPM4 channels in the cardiovascular system: physiology, pathophysiology, and pharmacology. Biochem Pharmacol 84:873-881

4. Arends B, Slump E, Spee B, Rothuizen J, Penning LC (2008) Hepatocyte growth factor improves viability after $\mathrm{H}_{2} \mathrm{O}_{2}$-induced toxicity in bile duct epithelial cells. Comp Biochem Physiol C Toxicol Pharmacol 147:324-330

5. Armisen R, Marcelain K, Simon F, Tapia JC, Toro J, Quest AF, Stutzin A (2011) TRPM4 enhances cell proliferation through upregulation of the beta-catenin signaling pathway. J Cell Physiol 226:103-109

6. Banasiak KJ, Burenkova O, Haddad GG (2004) Activation of voltage-sensitive sodium channels during oxygen deprivation leads to apoptotic neuronal death. Neuroscience 126:31-44

7. Barros LF, Hermosilla T, Castro J (2001) Necrotic volume increase and the early physiology of necrosis. Comp Biochem Physiol A Mol Integr Physiol 130:401-409

8. Barros LF, Stutzin A, Calixto A, Catalan M, Castro J, Hetz C, Hermosilla T (2001) Nonselective cation channels as effectors of free radical-induced rat liver cell necrosis. Hepatology 33:114-122

9. Becerra A, Echeverria C, Varela D, Sarmiento D, Armisen R, Nunez-Villena F, Montecinos M, Simon F (2011) Transient receptor potential melastatin 4 inhibition prevents lipopolysaccharideinduced endothelial cell death. Cardiovasc Res 91:677-684

10. Beis I, Newsholme EA (1975) The contents of adenine nucleotides, phosphagens and some glycolytic intermediates in resting muscles from vertebrates and invertebrates. Biochem J 152:23-32

11. Blaustein MP, Lederer WJ (1999) Sodium/calcium exchange: its physiological implications. Physiol Rev 79:763-854

12. Bortner CD, Cidlowski JA (2002) Apoptotic volume decrease and the incredible shrinking cell. Cell Death Differ 9:1307-1310

13. Bortner CD, Cidlowski JA (2003) Uncoupling cell shrinkage from apoptosis reveals that $\mathrm{Na}+$ influx is required for volume loss during programmed cell death. J Biol Chem 278:39176-39184

14. Bortner CD, Cidlowski JA (2007) Cell shrinkage and monovalent cation fluxes: role in apoptosis. Arch Biochem Biophys 462:176-188

15. Bortner CD, Gomez-Angelats M, Cidlowski JA (2001) Plasma membrane depolarization without repolarization is an early molecular event in anti-Fas-induced apoptosis. J Biol Chem 276:4304-4314
16. Brahma MK, Dohare P, Varma S, Rath SK, Garg P, Biswal PK, Chowdhury PD, Ray M (2009) The neuronal apoptotic death in global cerebral ischemia in gerbil: important role for sodium channel modulator. J Neurosci Res 87:1400-1411

17. Brayden JE, Earley S, Nelson MT, Reading S (2008) Transient receptor potential (TRP) channels, vascular tone and autoregulation of cerebral blood flow. Clin Exp Pharmacol Physiol 35:1116-1120

18. Bucchieri F, Puddicombe SM, Lordan JL, Richter A, Buchanan D, Wilson SJ, Ward J, Zummo G, Howarth PH, Djukanovic R, Holgate ST, Davies DE (2002) Asthmatic bronchial epithelium is more susceptible to oxidant-induced apoptosis. Am J Respir Cell Mol Biol 27:179-185

19. Callaway JK, Beart PM, Jarrott B, Giardina SF (2001) Incorporation of sodium channel blocking and free radical scavenging activities into a single drug, AM-36, results in profound inhibition of neuronal apoptosis. Br J Pharmacol 132:1691-1698

20. Carini R, Autelli R, Bellomo G, Albano E (1999) Alterations of cell volume regulation in the development of hepatocyte necrosis. Exp Cell Res 248:280-293

21. Chen J, Dai J, Grant RL, Doctor RB, Sheetz MP, Mandel LJ (1997) Loss of cytoskeletal support is not sufficient for anoxic plasma membrane disruption in renal cells. Am J Physiol 272:C1319-C1328

22. Chen J, Liu X, Mandel LJ, Schnellmann RG (2001) Progressive disruption of the plasma membrane during renal proximal tubule cellular injury. Toxicol Appl Pharmacol 171:1-11

23. Chen J, Wagner MC (2001) Altered membrane-cytoskeleton linkage and membrane blebbing in energy-depleted renal proximal tubular cells. Am J Physiol Renal Physiol 280:F619-F627

24. Chen M, Simard JM (2001) Cell swelling and a nonselective cation channel regulated by internal $\mathrm{Ca}^{2+}$ and ATP in native reactive astrocytes from adult rat brain. J Neurosci 21:6512-6521

25. Courageot MP, Lepine S, Hours M, Giraud F, Sulpice JC (2004) Involvement of sodium in early phosphatidylserine exposure and phospholipid scrambling induced by $\mathrm{P} 2 \mathrm{X} 7$ purinoceptor activation in thymocytes. J Biol Chem 279:21815-21823

26. Dai J, Sheetz MP (1999) Membrane tether formation from blebbing cells. Biophys J 77:3363-3370

27. Doctor RB, Zhelev DV, Mandel LJ (1997) Loss of plasma membrane structural support in ATP-depleted renal epithelia. Am J Physiol 272:C439-C449

28. Dong Z, Patel Y, Saikumar P, Weinberg JM, Venkatachalam MA (1998) Development of porous defects in plasma membranes of adenosine triphosphate-depleted Madin-Darby canine kidney cells and its inhibition by glycine. Lab Invest 78:657-668

29. Earley S, Reading S, Brayden JE (2007) Functional significance of transient receptor potential channels in vascular function. In: Liedtke WB, Heller S (eds) TRP ion channel function in sensory transduction and cellular signaling cascades, chapter 26. CRC Press, Boca Raton. http://www.crcpress.com/. Accessed 5 Sept 2012

30. Fang KM, Lee AS, Su MJ, Lin CL, Chien CL, Wu ML (2008) Free fatty acids act as endogenous ionophores, resulting in $\mathrm{Na}^{+}$and $\mathrm{Ca}^{2+}$ influx and myocyte apoptosis. Cardiovasc Res 78:533-545

31. Franco R, Bortner CD, Cidlowski JA (2006) Potential roles of electrogenic ion transport and plasma membrane depolarization in apoptosis. J Membr Biol 209:43-58

32. Freichel M, Almering J, Tsvilovskyy V (2012) The role of TRP proteins in mast cells. Front Immunol 3:150

33. Galluzzi L, Vanden Berghe T, Vanlangenakker N, Buettner S, Eisenberg T, Vandenabeele P, Madeo F, Kroemer G (2011) Programmed necrosis from molecules to health and disease. Int Rev Cell Mol Biol 289:1-35

34. Galluzzi L, Vitale I, Abrams JM, Alnemri ES, Baehrecke EH, Blagosklonny MV, Dawson TM, Dawson VL, El-Deiry WS, Fulda S, Gottlieb E, Green DR, Hengartner MO, Kepp O, Knight RA, Kumar S, Lipton SA, Lu X, Madeo F, Malorni W, Mehlen P, Nunez G, Peter ME, Piacentini M, Rubinsztein DC, Shi Y, Simon 
HU, Vandenabeele P, White E, Yuan J, Zhivotovsky B, Melino G, Kroemer G (2012) Molecular definitions of cell death subroutines: recommendations of the Nomenclature Committee on Cell Death 2012. Cell Death Differ 19:107-120

35. Gerzanich V, Woo SK, Vennekens R, Tsymbalyuk O, Ivanova S, Ivanov A, Geng Z, Chen Z, Nilius B, Flockerzi V, Freichel M, Simard JM (2009) De novo expression of Trpm4 initiates secondary hemorrhage in spinal cord injury. Nat Med 15:185-191

36. Gomez-Lazaro M, Galindo MF, Fernandez-Gomez FJ, Prehn JH, Jordan J (2005) Activation of p53 and the pro-apoptotic p53 target gene PUMA during depolarization-induced apoptosis of chromaffin cells. Exp Neurol 196:96-103

37. Guinamard R, Bois P (2007) Involvement of transient receptor potential proteins in cardiac hypertrophy. Biochim Biophys Acta 1772:885-894

38. Guinamard R, Demion M, Launay P (2010) Physiological roles of the TRPM4 channel extracted from background currents. Physiology (Bethesda) 25:155-164

39. Guinamard R, Demion M, Magaud C, Potreau D, Bois P (2006) Functional expression of the TRPM4 cationic current in ventricular cardiomyocytes from spontaneously hypertensive rats. Hypertension 48:587-594

40. Guinamard R, Salle L, Simard C (2011) The non-selective monovalent cationic channels TRPM4 and TRPM5. Adv Exp Med Biol 704:147-171

41. Gutierrez AA, Arias JM, Garcia L, Mas-Oliva J, GuerreroHernandez A (1999) Activation of a Ca2+-permeable cation channel by two different inducers of apoptosis in a human prostatic cancer cell line. J Physiol 517(Pt 1):95-107

42. Islam MS (2011) TRP channels of islets. Adv Exp Med Biol 704:811-830

43. Jeulin C, Dazy AC, Marano F (2002) Effects of hydrogen peroxide and hydroxyl radicals on the cytosolic side of a non-selective cation channel in the cultured human bronchial epithelial cell line 16HBE14o-. Pflugers Arch 443:574-583

44. Jordan J, Galindo MF, Calvo S, Gonzalez-Garcia C, Cena V (2000) Veratridine induces apoptotic death in bovine chromaffin cells through superoxide production. Br J Pharmacol 130:1496-1504

45. Jouan-Lanhouet S, Arshad MI, Piquet-Pellorce C, Martin-Chouly C, Le Moigne-Muller G, Van HF, Takahashi N, Sergent O, Lagadic-Gossmann D, Vandenabeele P, Samson M, DimancheBoitrel MT (2012) TRAIL induces necroptosis involving RIPK1/ RIPK3-dependent PARP-1 activation. Cell Death Differ. doi:10.1038/cdd.2012.90

46. Jurkowitz-Alexander MS, Altschuld RA, Hohl CM, Johnson JD, McDonald JS, Simmons TD, Horrocks LA (1992) Cell swelling, blebbing, and death are dependent on ATP depletion and independent of calcium during chemical hypoxia in a glial cell line (ROC-1). J Neurochem 59:344-352

47. Kerr JF, Wyllie AH, Currie AR (1972) Apoptosis: a basic biological phenomenon with wide-ranging implications in tissue kinetics. Br J Cancer 26:239-257

48. Kim JA, Kang YS, Jung MW, Lee SH, Lee YS (1999) Involvement of $\mathrm{Ca}^{2+}$ influx in the mechanism of tamoxifen-induced apoptosis in HepG2 human hepatoblastoma cells. Cancer Lett 147:115-123

49. Kinnally KW, Peixoto PM, Ryu SY, Dejean LM (2011) Is mPTP the gatekeeper for necrosis, apoptosis, or both? Biochim Biophys Acta 1813:616-622

50. Kroemer G, Galluzzi L, Vandenabeele P, Abrams J, Alnemri ES, Baehrecke EH, Blagosklonny MV, El-Deiry WS, Golstein P, Green DR, Hengartner M, Knight RA, Kumar S, Lipton SA, Malorni W, Nunez G, Peter ME, Tschopp J, Yuan J, Piacentini M, Zhivotovsky B, Melino G (2009) Classification of cell death: recommendations of the Nomenclature Committee on Cell Death 2009. Cell Death Differ 16:3-11
51. Kruse M, Schulze-Bahr E, Corfield V, Beckmann A, Stallmeyer B, Kurtbay G, Ohmert I, Schulze-Bahr E, Brink P, Pongs O (2009) Impaired endocytosis of the ion channel TRPM4 is associated with human progressive familial heart block type I. J Clin Invest 119:2737-2744

52. Lang F, Birka C, Myssina S, Lang KS, Lang PA, Tanneur V, Duranton C, Wieder T, Huber SM (2004) Erythrocyte ion channels in regulation of apoptosis. Adv Exp Med Biol 559:211-217

53. Lang F, Lang KS, Wieder T, Myssina S, Birka C, Lang PA, Kaiser S, Kempe D, Duranton C, Huber SM (2003) Cation channels, cell volume and the death of an erythrocyte. Pflugers Arch 447:121-125

54. Lang F, Ritter M, Gamper N, Huber S, Fillon S, Tanneur V, Lepple-Wienhues A, Szabo I, Gulbins E (2000) Cell volume in the regulation of cell proliferation and apoptotic cell death. Cell Physiol Biochem 10:417-428

55. Launay P, Cheng H, Srivatsan S, Penner R, Fleig A, Kinet JP (2004) TRPM4 regulates calcium oscillations after T cell activation. Science 306:1374-1377

56. Launay P, Fleig A, Perraud AL, Scharenberg AM, Penner R, Kinet JP (2002) TRPM4 is a $\mathrm{Ca}^{2+}$-activated nonselective cation channel mediating cell membrane depolarization. Cell 109:397-407

57. Lehen'kyi V, Prevarskaya N (2011) Oncogenic TRP channels. Adv Exp Med Biol 704:929-945

58. Leist M, Single B, Castoldi AF, Kuhnle S, Nicotera P (1997) Intracellular adenosine triphosphate (ATP) concentration: a switch in the decision between apoptosis and necrosis. J Exp Med 185:1481-1486

59. Liman ER (2007) The $\mathrm{Ca}^{2+}$-activated TRP channels: TRPM4 and TRPM5. In: Liedtke WB, Heller S (eds) TRP ion channel function in sensory transduction and cellular signaling cascades, chapter 15. CRC Press, Boca Raton. http://www.crcpress.com/. Accessed 5 Sept 2012

60. Liu H, El ZL, Kruse M, Guinamard R, Beckmann A, Bozio A, Kurtbay G, Megarbane A, Ohmert I, Blaysat G, Villain E, Pongs O, Bouvagnet P (2010) Gain-of-function mutations in TRPM4 cause autosomal dominant isolated cardiac conduction disease. Circ Cardiovasc Genet 3:374-385

61. Liu X, Schnellmann RG (2003) Calpain mediates progressive plasma membrane permeability and proteolysis of cytoskeletonassociated paxillin, talin, and vinculin during renal cell death. J Pharmacol Exp Ther 304:63-70

62. Liu X, Van VT, Schnellmann RG (2004) The role of calpain in oncotic cell death. Annu Rev Pharmacol Toxicol 44:349-370

63. Los M, Mozoluk M, Ferrari D, Stepczynska A, Stroh C, Renz A, Herceg Z, Wang ZQ, Schulze-Osthoff K (2002) Activation and caspase-mediated inhibition of PARP: a molecular switch between fibroblast necrosis and apoptosis in death receptor signaling. Mol Biol Cell 13:978-988

64. Manion MK, Su Z, Villain M, Blalock JE (2000) A new type of $\mathrm{Ca}(2+)$ channel blocker that targets $\mathrm{Ca}(2+)$ sensors and prevents $\mathrm{Ca}(2+)$-mediated apoptosis. FASEB J 14:1297-1306

65. Mathar I, Vennekens R, Meissner M, Kees F, Van der Mieren G, Camacho Londono JE, Uhl S, Voets T, Hummel B, van den Bergh A, Herijgers P, Nilius B, Flockerzi V, Schweda F, Freichel M (2010) Increased catecholamine secretion contributes to hypertension in TRPM4-deficient mice. J Clin Invest 120:32673279

66. McNulty S, Fonfria E (2005) The role of TRPM channels in cell death. Pflugers Arch 451:235-242

67. Miller BA (2006) The role of TRP channels in oxidative stressinduced cell death. J Membr Biol 209:31-41

68. Mills RW, Milan DJ (2010) TRPM4-linked isolated cardiac conduction defects: bad trafficking causes electrical gridlock. Circ Cardiovasc Genet 3:311-313

69. Miyamoto S, Howes AL, Adams JW, Dorn GW, Brown JH (2005) $\mathrm{Ca}^{2+}$ dysregulation induces mitochondrial depolarization 
and apoptosis: role of $\mathrm{Na}^{+} / \mathrm{Ca}^{2+}$ exchanger and AKT. J Biol Chem 280:38505-38512

70. Molitoris BA, Dahl R, Hosford M (1996) Cellular ATP depletion induces disruption of the spectrin cytoskeletal network. Am J Physiol 271:F790-F798

71. Mukherjee SB, Das M, Sudhandiran G, Shaha C (2002) Increase in cytosolic $\mathrm{Ca}^{2+}$ levels through the activation of non-selective cation channels induced by oxidative stress causes mitochondrial depolarization leading to apoptosis-like death in Leishmania donovani promastigotes. J Biol Chem 277:24717-24727

72. Murakami M, Xu F, Miyoshi I, Sato E, Ono K, Iijima T (2003) Identification and characterization of the murine TRPM4 channel. Biochem Biophys Res Commun 307:522-528

73. Neisch AL, Fehon RG (2011) Ezrin, Radixin and Moesin: key regulators of membrane-cortex interactions and signaling. Curr Opin Cell Biol 23:377-382

74. Nilius B, Owsianik G, Voets T, Peters JA (2007) Transient receptor potential cation channels in disease. Physiol Rev 87:165-217

75. Nilius B, Prenen J, Droogmans G, Voets T, Vennekens R, Freichel M, Wissenbach U, Flockerzi V (2003) Voltage dependence of the $\mathrm{Ca}^{2+}$ activated cation channel TRPM4. J Biol Chem 278:30813-30820

76. Nilius B, Prenen J, Janssens A, Owsianik G, Wang C, Zhu MX, Voets $T$ (2005) The selectivity filter of the cation channel TRPM4. J Biol Chem 280:22899-22906

77. Nilius B, Prenen J, Tang J, Wang C, Owsianik G, Janssens A, Voets $\mathrm{T}$, Zhu MX (2005) Regulation of the $\mathrm{Ca}^{2+}$ sensitivity of the nonselective cation channel TRPM4. J Biol Chem 280:6423-6433

78. Nilius B, Prenen J, Voets T, Droogmans G (2004) Intracellular nucleotides and polyamines inhibit the $\mathrm{Ca}^{2+}$-activated cation channel TRPM4b. Pflugers Arch 448:70-75

79. Nilius B, Vennekens R (2006) From cardiac cation channels to the molecular dissection of the transient receptor potential channel TRPM4. Pflugers Arch 453:313-321

80. Nilius B, Voets T, Peters J (2005) TRP channels in disease. Sci STKE 2005:re8

81. Nishida M, Kurose H (2008) Roles of TRP channels in the development of cardiac hypertrophy. Naunyn Schmiedebergs Arch Pharmacol 378:395-406

82. Ono K, Wang X, Kim SO, Armstrong LC, Bornstein P, Han J (2010) Metaxin deficiency alters mitochondrial membrane permeability and leads to resistance to TNF-induced cell killing. Protein Cell 1:161-173

83. Orlov SN, Hamet P (2004) Apoptosis vs. oncosis: role of cell volume and intracellular monovalent cations. Adv Exp Med Biol 559:219-233

84. Orlov SN, Hamet P (2006) The death of cardiotonic steroidtreated cells: evidence of $\mathrm{Na}+\mathrm{i}, \mathrm{K}+\mathrm{i}$-independent $\mathrm{H}+\mathrm{i}$-sensitive signalling. Acta Physiol (Oxf) 187:231-240

85. Orlov SN, Thorin-Trescases N, Kotelevtsev SV, Tremblay J, Hamet P (1999) Inversion of the intracellular $\mathrm{Na}^{+} / \mathrm{K}^{+}$ratio blocks apoptosis in vascular smooth muscle at a site upstream of caspase-3. J Biol Chem 274:16545-16552

86. Orlov SN, Thorin-Trescases N, Pchejetski D, Taurin S, Farhat N, Tremblay J, Thorin E, Hamet P (2004) $\mathrm{Na}^{+} / \mathrm{K}^{+}$pump and endothelial cell survival: $\left[\mathrm{Na}^{+}\right]_{\mathrm{i}} /\left[\mathrm{K}^{+}\right]_{\mathrm{i}}$-independent necrosis triggered by ouabain, and protection against apoptosis mediated by elevation of $\left[\mathrm{Na}^{+}\right]_{\mathrm{i}}$. Pflugers Arch 448:335-345

87. Panayiotidis MI, Bortner CD, Cidlowski JA (2006) On the mechanism of ionic regulation of apoptosis: would the $\mathrm{Na}^{+} / \mathrm{K}^{+}$-ATPase please stand up? Acta Physiol (Oxf) 187:205-215

88. Pivovarova NB, Andrews SB (2010) Calcium-dependent mitochondrial function and dysfunction in neurons. FEBS J 277:3622-3636

89. Prevarskaya N, Zhang L, Barritt G (2007) TRP channels in cancer. Biochim Biophys Acta 1772:937-946

90. Rasola A, Bernardi P (2011) Mitochondrial permeability transition in $\mathrm{Ca}(2+)$-dependent apoptosis and necrosis. Cell Calcium 50:222-233
91. Reading SA, Brayden JE (2007) Central role of TRPM4 channels in cerebral blood flow regulation. Stroke 38:2322-2328

92. Rivers DB, Rocco MM, Frayha AR (2002) Venom from the ectoparasitic wasp Nasonia vitripennis increases $\mathrm{Na}^{+}$influx and activates phospholipase $\mathrm{C}$ and phospholipase $\mathrm{A} 2$ dependent signal transduction pathways in cultured insect cells. Toxicon 40:9-21

93. Robertson GA (2009) Endocytic control of ion channel density as a target for cardiovascular disease. J Clin Invest 119:2531-2534

94. Rotsch C, Radmacher M (2000) Drug-induced changes of cytoskeletal structure and mechanics in fibroblasts: an atomic force microscopy study. Biophys J 78:520-535

95. Rubtsov AM, Lopina OD (2000) Ankyrins. FEBS Lett 482:1-5

96. Schwartz N, Hosford M, Sandoval RM, Wagner MC, Atkinson SJ, Bamburg J, Molitoris BA (1999) Ischemia activates actin depolymerizing factor: role in proximal tubule microvillar actin alterations. Am J Physiol 276:F544-F551

97. Shapovalov G, Lehen'kyi V, Skryma R, Prevarskaya N (2011) TRP channels in cell survival and cell death in normal and transformed cells. Cell Calcium 50:295-302

98. Simard JM, Tsymbalyuk O, Keledjian K, Ivanov A, Ivanova S, Gerzanich V (2012) Comparative effects of glibenclamide and riluzole in a rat model of severe cervical spinal cord injury. Exp Neurol 233:566-574

99. Simon F, Leiva-Salcedo E, Armisen R, Riveros A, Cerda O, Varela D, Eguiguren AL, Olivero P, Stutzin A (2010) Hydrogen peroxide removes TRPM4 current desensitization conferring increased vulnerability to necrotic cell death. J Biol Chem 285:37150-37158

100. Simon F, Varela D, Eguiguren AL, Diaz LF, Sala F, Stutzin A (2004) Hydroxyl radical activation of a $\mathrm{Ca}(2+)$-sensitive nonselective cation channel involved in epithelial cell necrosis. Am J Physiol Cell Physiol 287:C963-C970

101. Sook HM, Shin KJ, Kim YH, Kim SH, Lee T, Kim E, Ho RS, Suh PG (2003) Thiram and ziram stimulate non-selective cation channel and induce apoptosis in PC12 cells. Neurotoxicology $24: 425-434$

102. Stallmeyer B, Zumhagen S, Denjoy I, Duthoit G, Hebert JL, Ferrer X, Maugenre S, Schmitz W, Kirchhefer U, Schulze-Bahr E, Guicheney P, Schulze-Bahr E (2012) Mutational spectrum in the $\mathrm{Ca}(2+)$-activated cation channel gene TRPM4 in patients with cardiac conductance disturbances. Hum Mutat 33:109-117

103. Sudhandiran G, Shaha C (2003) Antimonial-induced increase in intracellular $\mathrm{Ca}^{2+}$ through non-selective cation channels in the host and the parasite is responsible for apoptosis of intracellular Leishmania donovani amastigotes. J Biol Chem 278:25120-25132

104. Tan HL, Fong WJ, Lee EH, Yap M, Choo A (2009) mAb 84, a cytotoxic antibody that kills undifferentiated human embryonic stem cells via oncosis. Stem Cells 27:1792-1801

105. Temkin V, Huang Q, Liu H, Osada H, Pope RM (2006) Inhibition of ADP/ATP exchange in receptor-interacting protein-mediated necrosis. Mol Cell Biol 26:2215-2225

106. Torgerson RR, McNiven MA (1998) The actin-myosin cytoskeleton mediates reversible agonist-induced membrane blebbing. J Cell Sci 111(Pt 19):2911-2922

107. Uchida K, Tominaga M (2011) The role of thermosensitive TRP (transient receptor potential) channels in insulin secretion. Endocr J 58:1021-1028

108. Ullrich ND, Voets T, Prenen J, Vennekens R, Talavera K, Droogmans $\mathrm{G}$, Nilius B (2005) Comparison of functional properties of the $\mathrm{Ca}^{2+}$ activated cation channels TRPM4 and TRPM5 from mice. Cell Calcium 37:267-278

109. Vandenabeele P, Galluzzi L, Vanden Berghe T, Kroemer G (2010) Molecular mechanisms of necroptosis: an ordered cellular explosion. Nat Rev Mol Cell Biol 11:700-714

110. Vennekens R, Nilius B (2007) Insights into TRPM4 function, regulation and physiological role. Handb Exp Pharmacol:269-285 
111. Vennekens R, Olausson J, Meissner M, Bloch W, Mathar I, Philipp SE, Schmitz F, Weissgerber P, Nilius B, Flockerzi V, Freichel M (2007) Increased IgE-dependent mast cell activation and anaphylactic responses in mice lacking the calcium-activated nonselective cation channel TRPM4. Nat Immunol 8:312-320

112. Vereninov AA, Goryachaya TS, Moshkov AV, Vassilieva IO, Yurinskaya VE, Lang F, Rubashkin AA (2007) Analysis of the monovalent ion fluxes in U937 cells under the balanced ion distribution: recognition of ion transporters responsible for changes in cell ion and water balance during apoptosis. Cell Biol Int 31:382-393

113. Wagner MC, Molitoris BA (1997) ATP depletion alters myosin I beta cellular location in LLC-PK1 cells. Am J Physiol 272: C1680-C1690

114. White P, Doctor RB, Dahl RH, Chen J (2000) Coincident microvillar actin bundle disruption and perinuclear actin sequestration in anoxic proximal tubule. Am J Physiol Renal Physiol 278:F886-F893

115. White P, Gu L, Chen J (2002) Decreased actin solubility observed during ATP-depletion is mimicked by severing agents but not depolymerizing agents in isolated and cultured proximal tubular cells. Clin Physiol Funct Imaging 22:312-319

116. Xiao AY, Wei L, Xia S, Rothman S, Yu SP (2002) Ionic mechanism of ouabain-induced concurrent apoptosis and necrosis in individual cultured cortical neurons. J Neurosci 22:1350-1362

117. Ye X, Wang Y, Yang M, Wang Q, Liang Q, Ma Z, Zhang B, Gao $Y$ (2009) Investigating the in vitro metabolism of veratridine: characterization of metabolites and involved cytochrome P450 isoforms. J Chromatogr B Analyt Technol Biomed Life Sci 877:141-148

118. Yu SP (2003) $\mathrm{Na}(+), \mathrm{K}(+)$-ATPase: the new face of an old player in pathogenesis and apoptotic/hybrid cell death. Biochem Pharmacol 66:1601-1609

119. Zhang T, Yong SL, Drinko JK, Popovic ZB, Shryock JC, Belardinelli L, Wang QK (2011) LQTS mutation N1325S in cardiac sodium channel gene SCN5A causes cardiomyocyte apoptosis, cardiac fibrosis and contractile dysfunction in mice. Int J Cardiol 147:239-245 